\title{
THE EFFECT OF KNOWLEDGE MANAGEMENT ON THE STRATEGIC MANAGEMENT PROCESS MEDIATED BY COMPETITIVE INTELLIGENCE IN THE SMALL BUSINESS COMPANY
}

\author{
Didi Sundiman \\ Department of Management, Universitas Universal, Batam, Indonesia \\ Email: sundiman.didi@gmail.com
}

\begin{abstract}
The purpose of this study is to discuss the synergic and separate use of knowledge management and competitive intelligence in stage of strategic management process. This study presents two independent variables (knowledge management and competitive intelligence) and one dependent variable (strategic management process). 145 samples from Indonesia small businesses considered valid, thereby indicating $88.41 \%$ validity rate. The results show that the proposed variable, Knowledge management and competitive intelligence significantly influences strategic management process from the perspective of the small business in West Indonesia. This result implies a lack of mediation effect presented by the competitive intelligence. This finding clarifies the research question that knowledge management and competitive intelligence are associated with strategic management process.
\end{abstract}

Keywords: Small business, Indonesia, knowledge management, strategic management, competitive intelligence.

\section{Introduction}

Competition in the digital age brings organizations to be able to see the patterns of competition that build faster. The digital era provides an opportunity for organizations to explore their resources more efficiently and effectively. Excellence in the field of technology brings many facilities for organizations to gather a variety of information related to their business from internal or external organizations. Technology and knowledge in organization support the process of efficiency of time and other resources within the organization (Hung, Lien, Fang, \& McLean, 2010; Zack, McKeen, \& Singh, 2009). Organizations with knowledge mastery capabilities will have an advantage in resource management processes (Bogza \& Zaharie, 2008; Nonaka \& Takeuchi, 1995; Sook-Ling, Ismail, \& Yee-Yen, 2015).

Knowledge is a very important part and should be involved in any decision making of the organization's strategy (Bartes, 2014; Giebels, van Buuren, \& Edelenbos, 2015; Ma, 1999). Knowledge-based strategy decisions have demonstrated a significant role for improving the quality of organizational management (Chen \& Huang, 2009; Sundiman \& Idrus, 2015; Zack et al., 2009). An organizational strategy formed from good knowledge management provides a great deal of evidence of success in more effective resource management within the organization (SookLing et al., 2015).
Small and medium enterprises (SMEs) have enormous challenges to survive and thrive in the digital age (Battisti, Deakins, \& Perry, 2013; Cerchione, Esposito, \& Spadaro, 2015; Sundiman, 2017; Verreynne \& Meyer, 2010). Competition requires organizations to be able to see the possibilities in the marketplace. Strengths, weaknesses, opportunities and threat must be able accurately analyzed by the organization. Many data show how weak the ability of small businesses in creating their business advantage in the face of very rapid changes (Battisti et al., 2013; Roxas, Battisti, \& Deakins, 2013; Verreynne \& Meyer, 2010). Resilient small businesses are those who can read and respond to market movements quickly. Small businesses capable of reading market needs will be able to respond to provide products needed by the market (Avlonitis \& Salavou, 2007; March-Chordà, Gunasekaran, \& Lloria-Aramburo, 2002; Adeniran, 2012).

Many studies show how small businesses lack the ability to manage knowledge for their organizations (Nunes, Annansingh, Eaglestone, \& Wakefield, 2006; Desouza \& Awazu, 2006; Harris, 2009; Purcarea, del Mar Benavides Espinosa, \& Apetrei, 2013). Researchers also show how weak the ability of small businesses to collect information and data from their environment. Weaknesses in the process of collecting data and information is causing the weakness of the company's strategic decision-making process in responding to the market (Chan, Huff, Barclay, \& Cope- 
land 1997; Intezari \& Gressel, 2017; Manoharan, Melitski, \& Bromberg, 2015; Ogiela, 2015).

Several studies in developing countries also show how the important role of small businesses in the economy (Abor \& Quartey, 2010; Jamali, LundThomsen, \& Jeppesen, 2017; Tambunan, 2008; Teima et al., 2010). The ability and flexibility that small businesses have in supporting the adaptation process in every environmental change quickly, so that small businesses can make the right decisions (Pak, Ra, \& Lee, 2015; Spithoven, Vanhaverbeke, \& Roijakkers, 2013; Villa \& Taurino, 2017; Whyman \& Petrescu, 2015). The mechanism of small businesses in the process of collecting data and information and then processsing the existing data and information into this knowledge becomes an interesting research topic studied, especially in developing countries (Linton \& Solomon, 2017; Nguyen, Newby, \& Macaulay, 2015; Street \& Meister, 2004; Sundiman, Mursidi, \& Putra, 2016; Wong \& Aspinwall, 2004). This study attempts to answer the questions of how small businesses develop their processing mechanisms and their surroundding environmental information, how small businesses process existing knowledge, and its influence in organizational strategy management processes.

\section{Knowledge Management in Organizations}

The definition of organizational resources has changed over the last few decades. Finance and physical material decades ago are the main resources, but the last one to two decades, knowledge has become one of the major resources for the organization (Nonaka \& Takeuchi, 1995; Shujahat et al., 2017; Sundiman et al., 2016; Zack et al., 2009). Nonaka divides knowledge into two large groups of tacit and explicit knowledge (Nonaka, 1994; Nonaka \& Takeuchi, 1995). The management of these two knowledge groups requires a different pattern. The organization's ability to create, collect, store, share and apply knowledge is an important part of the organization's current success. Research shows how the important role of good knowledge management contributes significantly to improving organizational performance (Cohen \& Olsen, 2015; Donate \& dePablo, 2015; Reich, Gemino, \& Sauer, 2014).

The efficiency of knowledge management provides a direct impact on the efficiency of other resource management (Cohen \& Olsen, 2015; Fidel, Schlesinger, \& Cervera, 2015; Wipawayangkool \& Teng, 2016a). The quality of knowledge management also determines how the quality of human resource management in general (Figueiredo, Pais, Monteiro,
\& Mónico, 2016; Sundiman, 2017). Good knowledge management supports the organization in reading every environmental change appropriately (Giebels $e t$ al., 2015; Revilla, Prieto, \& Prado, 2010). This is certainly very beneficial to the organization in the face of the rapid changes that occur with adaptation.

Upright knowledge management processes will create competitive advantage in the organization (Danskin, Englis, Solomon, Goldsmith, \& Davey, 2005; Davenport \& Prusak, 1997; Jennex, 2008; Ndlela \& DuToit, 2001; Newman, 1997; Nonaka \& Takeuchi, 1995; Rahimli, 2012; Shujahat et al., 2017). These competitive advantages make organizations able to deal with any emerging competition to satisfy consumers. Organizations continue to create new knowledge to read patterns of market changes (Darroch \& McNaughton, 2003; Jamil, 2013; Kamya, Ntayi, \& Ahiauzu, 2010; Teece, Pisano, \& Shuen, 1997; Tidd, 2003). New knowledge of market conditions provides a clear picture for the organization in every decision of their decisions. The knowledge that been created within the organization must be well stored. The process of storing knowledge within organizations supports the sustainability of knowledge management processes within organizations (Bogza \& Zaharie, 2008; Cvitanovic, Hobday, vanKerkhoff, $\&$ Marshall, 2015). The process of sharing knowledge in an organization is a phase in which the stored knowledge must be immediately distributed to various parties as a supporter of the decision-making process. The process of sharing quality knowledge supports a fast and timely decision-making process (Boden, Avram, Bannon, \& Wulf, 2012; Ford, Myrden, \& Jones, 2015; Liang, Liu, \& Wu, 2008; Nesheim \& Gressgård, 2014; Vajjhala, 2013; Werner, Dickson, \&Hyde, 2015). The latest knowledge applications in organizational operations and the latest decisive success of policy execution in today's organizations (Cerchione et al., 2015; Kraaijenbrink, 2012; Liao, 2003; Plessis, 2007; Revilla et al., 2010).

\section{Competitive Intelligence within the Organization}

Organizations must be able to collect data and information quickly and accurately. Rapid changes due to the support of digital technology make the flow of data and information undergoes a very dynamic change (Intezari \& Gressel, 2017; Sook-Ling et al., 2015). The business operational pattern is changing very fast, it is driving the dynamic pattern of business competition (Verreynne \& Meyer, 2010). Organizations must be able to collect the best data and information from highly dynamic markets. Each organization continues to develop their ability to capture 
information and data circulating in the market. With the help of information technology and the latest management pattern, the organization builds the best competitive intelligence to address every dynamic change in the marketplace (Jamil, 2013; Marin \& Poulter, 2004; Pargaonkar, 2016; Vriens, 2004).

Quality of data and information becomes very important in determining the organization's strategic decision-making process (Malakooti, 2012; Oppenheimer \& Kelso, 2015). Many distortions happen in dynamic markets. Organizations must be able to sort and select good quality data according to the organization's need to cope with market changes (Bogza \& Zaharie, 2008). Technological developments and the progress of organizational governance generate large amounts of data and information. Not all data and information is useful for organizational operations. The organization's ability to select and retrieve appropriate data and information has a significant positive impact on the organization's strategy development process (Drnevich \& Croson, 2013; Zammuto, Griffith, Majchrzak, Dougherty, \& Faraj, 2007). The data and information gathered by the organization processed further in order to generate meaningful abusing for the organization. Any policy that taken by the organization using the basic results of data and information (Vriens, 2004; Zammuto et al., 2007).

Organizational intelligence in reading environmental conditions becomes an important part of strategic policymaking process (Akgün, Byrne, \& Keskin, 2007; Burton, Geishecker, Hostmann, Friedman, \& Newman, 2006; Davenport, 2010; Miner, 2002). Organizations that have competitive intelligence and use their optimally will be better able to read every opportunity and challenge that will arise. The rapidly changing market competition forces organizations to continue to improve their competitive intelligence (April \& Bessa, 2006; Calof \& Wright, 2008; Calof \& Smith, 2010; Ettorre, 1995; Jamil, 2013; Petrisor \& Strain, 2013; Rouach \& Santi, 2001; Shujahat et al., 2017; Trim \& Lee, 2008).

The organization analyzes every data and information that goes in accurately. The analysis process usually done by re-filtering data and information (Zammuto et al., 2007). Screening results used in the next analysis process to obtain useful information as a decision-making guide. The competitive intelligence in the organization includes the organizational ability to collect and then analyze the data and information obtained (Wolf, Just, \& Zilberman, 2001; Zammuto et al., 2007). As part of the competitive intelligence, the analysis process is an ongoing process that is not separate after the process of collecting data and information. Organizations capable of managing this sustainable process demonstrate significantly the benefits of operational quality improvement.

The next important step in competitive intelligence is the process of using data and information that has been collected and analyzed before. The accuracy of the process of applying data and information in the organization's operations will maximize the process of utilizing all of the organization's resources (Bergeron \& Hiller, 2005; Ettorre, 1995; Håkansson \& Nelke, 2015; Marin \& Poulter, 2004; Rouach \& Santi, 2001; Vriens, 2004). The efficiency of resources from the utilization of competitive intelligence can improve the operational efficiency of the organization (Bose, 2008; Marin \& Poulter, 2004; Rouach \& Santi, 2001).

\section{Knowledge Management and Competitive Intelligence in Organizational Strategic Management}

Organizations continue to refine their strategy policies. Rapid market changes due to globalization and technological advances encourage organizations to be able to adapt quickly (Cvitanovic et al., 2015). The strategy policy will determine whether the organization is on the right track to face any competition. Many studies show a significant role of knowledge management in the organization's strategic policy determination process (Nunes et al., 2006; Cohen \& Olsen, 2015; Shujahat et al., 2017; Teece et al., 1997; Wipawayangkool \& Teng, 2016b). Organizational strategic policies based on knowledge management show a significant positive role (Bollinger \& Smith, 2001; Donate \& dePablo, 2015; Roxas et al., 2013; Teece et al., 1997). The more qualified knowledge management in the organization will support the policy-making process and implementation of organizational strategies that support performance improvement (Birasnav, 2014; Zack et al., 2009). Integration of knowledge management in the policy making process of organizational strategy provides the ability for the organization to evaluate ongoing strategies and improve organizational strategy in the future. Previous studies show a significant role of knowledge management in the process of developing and enhancing the reliability of organizational strategy in the face of dynamic markets (Birasnav, 2014; Reich et al., 2014; Zack et al., 2009), so that we can form a research hypothesis that,

$H_{1}$ : Knowledge management in the organization significantly positively influences the organization's strategy management process.

Whereas competitive intelligence can forecast potential problems in external environment and 
provide their solutions (Bergeron \& Hiller, 2005; Calof \& Wright, 2008; Ettorre, 1995; Shujahat et al., 2017). When organizations are able properly account for the various market possibilities, the organization is able to anticipate with various steps to deal with dynamic change. It also offers advantages in the strategic planning (Bartes, 2014; Calof, Richards, \& Smith, 2015; Rouach \& Santi, 2001). Therefore, these two evidences combined in the separate management and strategic synergic way in the strategic management process (April \& Bessa, 2006). Knowledge management and competitive intelligence have crucial implications and impact on mission of the organization and vice versa. An organization aligns its knowledge management function and strategy with its vision and mission. Thus in this way they each drive (Akhter, 2003; Halawi, Aronson, \& Mccarthy, 2005; Liebowitz, 2001; Oztemel \& Arslankaya, 2012; Snyman \& Kruger, 2004). This also referred to in the case of competitive intelligence, which drives the mission of the organization.

Previous studies have demonstrated the significant role of competitive intelligence in the process of developing and enhancing the reliability of organizational strategy in the face of any market changes, so that we can form a research hypothesis,

$\mathrm{H}_{2}$ : Competitive intelligence significantly positively affects the strategic management process within the organization.

$H_{3}$ : Competitive intelligence mediates the indirect effect of knowledge management on the improvement of strategic management poses of organizations.

\section{Research Method}

\section{Research Model}

Previous studies have become the basis for the development of this research model. Figure 1. Illustrates the research model of the literature in general and research arguments in particular.

This study presents two independent variables (i.e., knowledge management and competitive intelligence) and one dependent variable (strategic management process). Competitive intelligence is the mediator between knowledge management and strategic management process. Details described as follows.

\section{Measure and Sample}

The questionnaire designed based on the literature and research arguments as the data collection instrument (see Table 2. in extracted form). This section describes the scales used to measure knowledge management processes, competitive intelligence and strategic management process. All the variables measured on six-point Likert scales ranging from one (1) strongly disagree to six (6) - strongly agree.

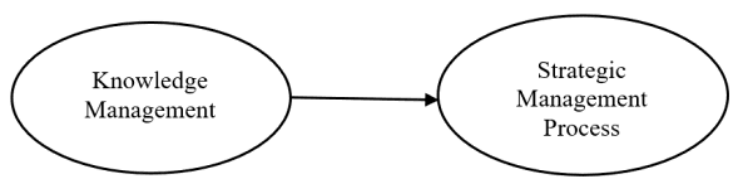

Model 1a. The effect of knowledge management on strategic management process

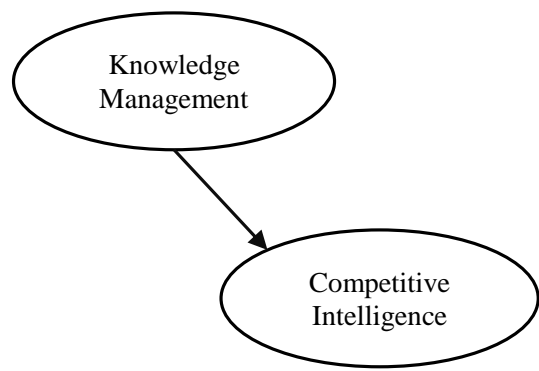

Model 1b. The effect of knowledge management on competitive intelligence

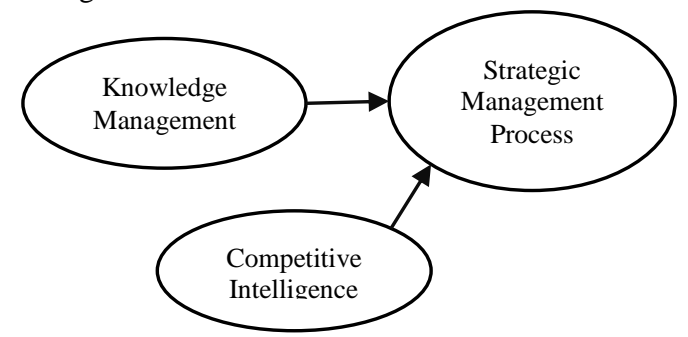

Model 2. Mediation effect of competitive intelligence between knowledge management and strategic management process

\section{Figure 1. Research model}

Knowledge management processes, the scale of knowledge management made by Gold, Malhotra, \& Segars (2001) and Zaim, Tatoglu, \& Zaim (2007). Items for knowledge management built after the literature review and extensive discussions with academics and chief executives during the pre-testing phase of the questionnaire development. Competitive intelligence, this scale was adapted from Bose (2008) and Calof and Wright (2008) scale, and includes 3 (three) items to measure the variable. Strategic management process, 3 (three) items indicators used to measure strategic management process, previous strategy research has used similar indirect measures of firm strategic management process (Shujahat et al., 2017). The respondents asked to indicate how the strategic management process was in their organization. A pilot test with multiple individuals conducted to understandability and readability. Eleven (11) items developed to describe the variables in the questionnaire. 
The basic information of the subjects includes gender, age, company type (e.g., service industry), CEO / manager of education, and job seniority (years). The sample targeted in the small business in West of Indonesia (Sumatera and Java Island) which experienced in using social network. The current study did not limit the top $\mathrm{N}$ companies due to the concerns of wide range of creation in product, process, and management. Therefore, an online questionnaire was developed and released in online communities (e.g., E-mail, Facebook and LinkedIn). A small business for manufacturing, retailing and service industries.

\section{Result and Discussion}

The number of questionnaires that successfully distributed in this study were 220 questionnaires. 164 questionnaires were collected and 145 were considered valid, thereby indicating $88.41 \%$ validity rate. Any returned questionnaire considered invalid if it is incomplete, not within the domains, or comprising a single answer.

\section{Descriptive Statistics}

Descriptive statistic data indicate small medium enterprises (SMEs) manager dominated by male gender as much as $68.96 \%$ with almost equal education level between high-educated small businesses managers and small businesses low educated managers. Table 1 presents the sample statistics.

Table 1

Descriptive Statistics

\begin{tabular}{|c|c|c|c|}
\hline \multicolumn{4}{|c|}{ Number of valid sample: 145} \\
\hline \multicolumn{2}{|l|}{ Basic data } & \multirow{2}{*}{$\begin{array}{c}\text { Samples } \\
100\end{array}$} & \multirow{2}{*}{$\begin{array}{r}\text { Percentage } \\
68.96 \%\end{array}$} \\
\hline Gender of the & Male & & \\
\hline coordinator & Female & 45 & $31.04 \%$ \\
\hline Age of the small & Age $\leqq 5$ & 70 & $48.28 \%$ \\
\hline business (years) & $6 \leqq$ Age $\leqq 10$ & 41 & $28.28 \%$ \\
\hline \multirow{4}{*}{ Company types } & $11 \leqq \mathrm{Age} \leqq 20$ & 24 & $16.55 \%$ \\
\hline & $20 \leqq$ Age & 10 & $6.90 \%$ \\
\hline & Manufacturing & 19 & $13.10 \%$ \\
\hline & Service & 45 & $31.03 \%$ \\
\hline \multirow{3}{*}{$\begin{array}{l}\text { Education of the } \\
\text { coordinator }\end{array}$} & Retailing & 81 & $55.86 \%$ \\
\hline & Higher education & 86 & $59.31 \%$ \\
\hline & $\begin{array}{l}\text { Non higher } \\
\text { education }\end{array}$ & 59 & $40.69 \%$ \\
\hline
\end{tabular}

$\overline{\text { Other descriptive data do not show significant things in the }}$ samples taken.

\section{Reliability and Factor Analysis}

Cronbach's Alpha used to confirm the internal consistency for the variables.
Table 2

Reliability and Factor Analyses Results

\begin{tabular}{|c|c|c|}
\hline $\begin{array}{l}\text { Question items } \\
\text { KM }\end{array}$ & $\begin{array}{c}\text { Item to } \\
\text { total }\end{array}$ & $\begin{array}{c}\text { Cronbach's } \\
\qquad \alpha\end{array}$ \\
\hline $\begin{array}{l}\text { Our business continues to create } \\
\text { new knowledge in the future }\end{array}$ & 0.814 & 0.894 \\
\hline $\begin{array}{l}\text { Our business is committed to } \\
\text { sharing knowledge equally } \\
\text { to all parts }\end{array}$ & 0.884 & \\
\hline $\begin{array}{l}\text { Our business has facilities to } \\
\text { support knowledge sharing } \\
\text { process }\end{array}$ & 0.868 & \\
\hline $\begin{array}{l}\text { Our business is committed to } \\
\text { applying new knowledge in } \\
\text { daily operations }\end{array}$ & 0.849 & \\
\hline $\begin{array}{l}\text { Our business applies knowledge } \\
\text { to solve every new problem } \\
\text { that arises }\end{array}$ & 0.781 & \\
\hline $\mathrm{CI}$ & & \\
\hline $\begin{array}{l}\text { Our organization collects data } \\
\text { and information regarding } \\
\text { market conditions and } \\
\text { competitors }\end{array}$ & 0.900 & 0.886 \\
\hline $\begin{array}{l}\text { Our organization analyzes data } \\
\text { and information regarding } \\
\text { market conditions and } \\
\text { competition }\end{array}$ & 0.914 & \\
\hline $\begin{array}{l}\text { Our organization uses market- } \\
\text { related data and information } \\
\text { for decision-making }\end{array}$ & 0.895 & \\
\hline \multicolumn{3}{|l|}{ SMP } \\
\hline $\begin{array}{l}\text { Our organization plans the } \\
\text { strategy systematically }\end{array}$ & 0.904 & 0.918 \\
\hline $\begin{array}{l}\text { Our organization executes a } \\
\text { strategy with commitment } \\
\text { and consistency }\end{array}$ & 0.942 & \\
\hline $\begin{array}{l}\text { Our organization evaluates } \\
\text { continuous improvement of } \\
\text { strategy }\end{array}$ & 0.934 & \\
\hline
\end{tabular}

KM: Knowledge Management; CI: Competitive Intelligence; SMP: Strategic Management Process

Table 2 presents the results of the reliability and factor analyses. The Cronbach's Alpha value increases if any item that suited the criteria deleted. Exploratory factor analysis employed to derive the actual factors. In particular, the knowledge management, competitive intelligence and Strategic management process variables grouped into a single factor. The validity test results obtained satisfied the following requirements: (1) item loading above 0.35 , which is not high but acceptable; (2) composite reliability (i.e., Cronbach's $\alpha$ ) above 0.6.

\section{Test Results}

Table 3 presents the results of the hypothesis tests. In particular, the results show that the proposed variable (i.e., knowledge management) significantly 
influences strategic management process from the perspective of the small business in West Indonesia (in Model (1)). Thus, $H_{l}(t=8.284, p=0.000)$ is supported. This finding indicates that knowledge management is associated with that of the strategic management process rule by the SME.

\section{Table 3}

\section{Results of the Hypothesis Tests}

Result for model (1) and (1b)

$\begin{array}{cc}\text { Strategic } & \text { Competitive } \\ \text { Management } & \text { Intelligence }\end{array}$

Process

\begin{tabular}{lllll}
\hline & \multicolumn{2}{l}{ Model (1) } & \multicolumn{2}{l}{ Model (1b) } \\
Independent & $t$ & $p$-value & $t$ & $p$-value \\
Knowledge & 8.284 & 0.000 & 8.698 & 0.000 \\
Management & & & & \\
$R^{2}$ & & 0.324 & & 0.346 \\
$\left(H_{l}\right)$ supported & & & \\
\hline
\end{tabular}

Result for model (2)

\begin{tabular}{lll}
\hline & \multicolumn{2}{c}{ Strategic Management Process } \\
\hline & Model (2) & \\
Independent & $t$ & -value \\
Knowledge & 2.695 & 0.008 \\
Management & & \\
Competitive & 10.622 & 0.000 \\
Intelligence & \multicolumn{2}{c}{0.623} \\
$R^{2}$ & \\
$\left(H_{2}\right)$ supported and $\left(H_{3}\right)$ not supported \\
\hline
\end{tabular}

Moreover, the effect of competitive intelligence on strategic management process is significant $(t=$ 8.698, $\left.p=0.000, R^{2}=0.346\right), H_{2}$ are supported. However, when the mediator (i.e., structural exchange) is introduced into the model (Model (2)), the $t$ value is reduced from 2.284 to 2.695 and $R^{2}$ is increased from 0.324 to 0.623 , but its effect remains significant $(p=0.008)$. This result implies a lack of mediation effect presented by the competitive intelligence. Thus, $H_{3}$ not supported. This finding clarifies the research question that knowledge management and competitive intelligence are associated with strategic management process.

\section{Conclusion and Implication}

The current research confirms the significance of knowledge management, and competitive intelligence, have significant effect to strategic management process in small medium enterprises. However, this study does not confirm the significance of competitive intelligence as the mediator between knowledge management and strategic management process.
First, knowledge management has a positive and significant impact on the strategic management process (see Table 3). These results support the results of research from many researchers (Nunes et al., 2006; Birasnav, 2014; Cohen \& Olsen, 2015; Donate \& dePablo, 2015; Shujahat et al., 2017; Teece et al., 1997; Wipawayangkool \& Teng, 2016b; Zack et al., 2009). Studies show a significant role of knowledge management in the organization's strategic policy determination process. Organizational strategic policies based on knowledge management show a significant positive role. Organizations continue to refine their strategy policies. Rapid market changes due to globalization and technological advances encourage organizations to be able to adapt quickly. The more qualified knowledge management in the organization will support the policy-making process and implementation of organizational strategies that support performance improvement. Integration of knowledge management in the policy making process of organizational strategy provides the ability for the organization to evaluate ongoing strategies and improve organizational strategy in the future. Previous studies show a significant role of knowledge management in the process of developing and enhancing the reliability of organizational strategy in the face of dynamic markets. The strategy policy will determine whether the organization is on the right track to face any competition.

Second, this research show that competitive intelligence significantly positively affects the strategic management process within the organization, as many studies have shown similar results (Bartes, 2014; Bergeron \& Hiller, 2005; Calof \& Wright, 2008; Calof et al., 2015; Ettorre, 1995; Rouach \& Santi, 2001; Shujahat et al., 2017). Whereas competitive intelligence can forecast potential problems in external environment and provide their solutions. How organization collects data and information, how organization analyzes data and information regarding market conditions and competition and how organization uses market-related data and information for decisionmaking giving significant effect on how organization plans the strategy systematically, executes a strategy with commitment and consistency and evaluates continuous improvement of strategy. When organizations are able properly account for the various market possibilities, the organization is able to anticipate with various steps to deal with dynamic change. It also offers advantages in the strategic planning.

Finally, the knowledge management process in organizational competition mechanisms encourages every process of strategic management decision in 
organization. On the one hand, competitive intelligence as an important part of the organization together with the KM process poses a significant positive impact on the quality of strategic management processes within the organization. The process in organization to create new knowledge in the future, commitment to sharing knowledge equally to all parts, the facilities to support knowledge sharing process significantly support organization to plans the strategy systematically. When organization application the new knowledge in daily operations to solve every new problem that arises will help organization to execute a strategy with commitment and consistency and evaluates continuous improvement of strategy better.

\section{References}

Abor, J., \& Quartey, P. (2010). Issues in sme development in Ghana and South Africa. International Research Journal of Finance and Economics, 39(39), 218-228.

Adeniran, T. V. (2012). Investigating the dynamic capabilities and competitive advantage of South African smes. African Journal of Business Management, 6(11), 4088-4099.

Akgün, A. E., Byrne, J., \& Keskin, H. (2007). Organizational intelligence: A structuration view. Journal of Organizational Change Management, 20(3), 272-289.

Akhter, S. H. (2003). Strategic planning, hypercompetition, and knowledge management. Business Horizons, 46(1), 19-24.

April, K., \& Bessa, J. (2006). A critique of the strategic competitive intelligence process within a global energy multinational. Problems and Perspectives in Management, 4(2), 86-99.

Avlonitis, G. J., \& Salavou, H. E. (2007). Entrepreneurial orientation of SMEs, product innovativeness, and performance. Journal of Business Research, 60 (5), 566-575.

Bartes, F. (2014). The objectives of competitive intelligence as a part of corporative development strategy. Acta Universitatis Agriculturae et Silviculturae Mendelianae Brunensis, 62(6), 12431250.

Battisti, M., Deakins, D., \& Perry, M. (2013). The sustainability of small businesses in recessionary times: Evidence from the strategies of urban and rural small businesses in New Zealand. International Journal of Entrepreneurial Behavior \& Research, 19(1), 72-96.

Bergeron, P., \& Hiller, C. A. (2005). Competitive intelligence. Annual Review of Information Science and Technology, 36(1), 353-390.
Birasnav, M. (2014). Knowledge management and organizational performance in the service industry: The role of transformational leadership beyond the effects of transactional leadership. Journal of Business Research, 67(8), 16221629.

Boden, A., Avram, G., Bannon, L., \&Wulf, V. (2012). Knowledge sharing practices and the impact of cultural factors: reflections on two case studies of offshoring in sme. Journal of Software: Evolution and Process, 24(2), 139152.

Bogza, R. M., \& Zaharie, D. (2008). Business intelligence as a competitive differentiator. In 2008 IEEE International Conference on Automation, Quality and Testing, Robotics, AQTR 2008 THETA 16th Edition - Proceedings (Vol. 1, pp. 146-151).

Bollinger, A. S., \& Smith, R. D. (2001). Managing organizational knowledge as a strategic asset. Journal of Knowledge Management, 5(1), 8-18.

Bose, R. (2008). Competitive intelligence process and tools for intelligence analysis. Industrial Management \& Data Systems, 108(4), 510-528.

Burton, B., Geishecker, L., Hostmann, B., Friedman, T., \& Newman, D. (2006). Organizational structure: Business intelligence and information management. Gartner Research, (April), 1-11.

Calof, J. L., Richards, G., \& Smith, J. (2015). Foresight, competitive intelligence and business analytics - Tools for making industrial programmes more efficient. Foresight-Russia, 9(1), 6881.

Calof, J. L., \& Smith, J. (2010). The integrative domain of foresight and competitive intelligence and its impact on r\&d management. $R \& D$ Management, 40(1), 31-39.

Calof, J. L., \& Wright, S. (2008). Competitive intelligence. European Journal of Marketing, 42(7/8), 717-730.

Cerchione, R., Esposito, E., \& Spadaro, M. R. (2015). The spread of knowledge management in smes: A scenario in evolution. Sustainability (Switzerland), 7(8), 10210-10232.

Chan, Y. E., Huff, S. L., Barclay, D. W., \& Copeland, D. G. (1997). Business strategic orientation, information systems strategic orientation, and strategic alignment. Information Systems Research, 8(2), 125-150.

Chen, C.-J., \& Huang, J.-W. (2009). Strategic human resource practices and innovation performance The mediating role of knowledge management capacity. Journal of Business Research, 62(1), 104-114. 
Cohen, J. F., \& Olsen, K. (2015). Knowledge management capabilities and firm performance: A test of universalistic, contingency and complementarity perspectives. Expert Systems with Applications, 42(3), 1178-1188.

Cvitanovic, C., Hobday, A. J., vanKerkhoff, L., \& Marshall, N. A. (2015). Overcoming barriers to knowledge exchange for adaptive resource management: The perspectives of Australian marine scientists. Marine Policy, 52, 38-44.

Danskin, P., Englis, B. G., Solomon, M. R., Goldsmith, M., \& Davey, J. (2005). Knowledge management as competitive advantage: Lessons from the textile and apparel value chain. Journal of Knowledge Management, 9(2), 91-102.

Darroch, J., \& McNaughton, R. (2003). Beyond market orientation: Knowledge management and the innovativeness of New Zealand firms. European Journal of Marketing, 37(3/4), 572593.

Davenport, T. H. (2010). Business intelligence and organizational decisions. International Journal of Business Intelligence Research, 1(1), 1-12.

Davenport, T. H., \& Prusak, L. (1997). Working knowledge: How organizations manage what they know. Boston, MA, USA: Harvard Business School Press.

Desouza, K. C., \& Awazu, Y. (2006). Knowledge management at smes: Five peculiarities. Journal of Knowledge Management, 10(1), 32-43.

Donate, M. J., \& dePablo, J. D. (2015). The role of knowledge-oriented leadership in knowledge management practices and innovation. Journal of Business Research, 68(2), 360-370.

Drnevich, P. L., \& Croson, D. C. (2013). Information technology and business-level strategy: Toward an integrated theoretical perspective. MIS Quarterly, 37(2), 483-509.

Ettorre, B. (1995). Managing competitive intelligence. Management Review, 84(10), 15-19.

Fidel, P., Schlesinger, W., \& Cervera, A. (2015). Collaborating to innovate: Effects on customer knowledge management and performance. Journal of Business Research, 68(7), 1426-1428.

Figueiredo, E., Pais, L., Monteiro, S., \& Mónico, L. (2016). Human resource management impact on knowledge management: Evidence from the Portuguese banking sector. Journal of Service Theory and Practice, 26(4), 497-528.

Ford, D., Myrden, S. E., \& Jones, T. D. (2015). Understanding "disengagement from knowledge sharing": Engagement theory versus adaptive cost theory. Journal of Knowledge Management, 19(3), 476-496.
Giebels, D., vanBuuren, A., \& Edelenbos, J. (2015). Using knowledge in a complex decision-making process - Evidence and principles from the Danish Houting project's ecosystem-based management approach. Environmental Science \& Policy, 47, 53-67.

Gold, A. H., Malhotra, A., \& Segars, A. H. (2001). Knowledge management: An organizational capabilities perspective. Journal of Management Information Systems, 18(1), 185-214.

Håkansson, C., \& Nelke, M. (2015). Competitive intelligence for information professionals. $1^{\text {st }} \mathrm{Ed}$. Waltham, MA: Chandos Publishing.

Halawi, L. A., Aronson, J. E., \& Mccarthy, R.V. (2005). Resource-based view of knowledge management for competitive advantage. Journal of Knowledge Management, 3(2), 75-86.

Harris, R. J. (2009). Improving tacit knowledge transfer within smes through e-collaboration. Journal of European Industrial Training, 33(3), 215-231.

Hung, R. Y.-Y., Lien, B. Y.-H., Fang, S.-C., \& McLean, G. N. (2010). Knowledge as a facilitator for enhancing innovation performance through total quality management. Total Quality Management \& Business Excellence, 21(4), 425-438.

Intezari, A., \& Gressel, S. (2017). Information and reformation in km systems: Big data and strategic decision-making. Journal of Knowledge Management, 21(1), 71-91.

Jamali, D., Lund-Thomsen, P., \& Jeppesen, S. (2017). Smes and csr in developing countries. Business and Society, 56(1), 11-22.

Jamil, G. L. (2013). Approaching market intelligence concept through a case analysis: Continuous knowledge for marketing strategic management and its complementarity to competitive intelligence. Procedia Technology, 9, 463-472.

Jennex, M. E. (2008). Knowledge management, organizational memory and transfer behavior: Global approaches and advancements. IGI Global.

Kamya, M. T., Ntayi, J. M., \& Ahiauzu, A. (2010). Knowledge management and competitive advantage: The interaction effect of market orientation. African Journal of Business Management, 4(14), 2971-2980.

Kraaijenbrink, J. (2012). Integrating knowledge and knowledge processes: A critical incident study of product development projects. Journal of Product Innovation Management, 29(6), 10821096.

Liang, T., Liu, C.-C., \& Wu, C.-H. (2008). Can social exchange theory explain individual knowledge- 
sharing behavior? A meta-analysis. Twenty Ninth International Conference on Information Systems, 18.

Liao, S. (2003). Knowledge management technologies and applications - literature review from 1995 to 2002. Expert Systems with Applications, 25(2), 155-164.

Liebowitz, J. (2001). Knowledge management and its link to artificial intelligence. Expert Systems with Applications, 20(1), 1-6.

Linton, J. D., \& Solomon, G. T. (2017). Technology, innovation, entrepreneurship and the small business: Technology and innovation in small business. Journal of Small Business Management, 55(2), $196-199$.

Ma, H. (1999). Creation and preemption for competitive advantage. Management Decision, 37(3), 259-267.

Malakooti, B. (2012). Decision making process: Typology, intelligence, and optimization. Journal of Intelligent Manufacturing, 23(3), 733-746.

Manoharan, A., Melitski, J., \& Bromberg, D. (2015). State strategic information system plans: An assessment integrating strategy and operations through performance measurement. International Journal of Public Sector Management, 28(3), 240-253.

March-Chordà, I., Gunasekaran, A., \& Lloria-Aramburo, B. (2002). Product development process in Spanish smes: An empirical research. Technovation, 22(5), 301-312.

Marin, J., \& Poulter, A. (2004). Dissemination of competitive intelligence. Journal of Information Science, 20(2), 165-180.

Miner, A. S. (2002). The pursuit of organizational intelligence. Administrative Science Quarterly, 47(1), 174-178.

Ndlela, L. T., \& DuToit, A. S. A. (2001). Establishing a knowledge management programme for competitive advantage in an enterprise. International Journal of Information Management, 21(2), 151-165.

Nesheim, T., \& Gressgård, L. J. (2014). Knowledge sharing in a complex organization: Antecedents and safety effects. Safety Science, 62, 28-36.

Newman, V. (1997). Redefining knowledge management to deliver competitive advantage. Journal of Knowledge Management, 1(2), 123-128.

Nguyen, T. H., Newby, M., \& Macaulay, M. J. (2015). Information technology adoption in small business: Confirmation of a proposed framework. Journal of Small Business Management, 53(1), 207-227.

Nonaka, I. (1994). A Dynamic Theory of organizational knowledge creation ikujiro nonaka. Organization Science, 5(1), 14-37.
Nonaka, I., \& Takeuchi, H. (1995). Knowledge-creating company: How Japanese companies create the dynamics of innovation. UK: Oxford University Press.

Nunes, M. B., Annansingh, F., Eaglestone, B., \& Wakefield, R. (2006). Knowledge management issues in knowledge-intensive SMEs. Journal of Documentation, 62(1), 101-119.

Ogiela, L. (2015). Advanced techniques for knowledge management and access to strategic information. International Journal of Information Management, 35 (2), 154-159.

Oppenheimer, D. M., \& Kelso, E. (2015). Information processing as a paradigm for decision making. Annual Review of Psychology, 66(1), 277-294.

Oztemel, E., \& Arslankaya, S. (2012). Enterprise knowledge management model: A knowledge tower. Knowledge and Information Systems, 31(1), 171-192.

Pak, Y. S., Ra, W., \& Lee, J. M. (2015). An integrated multi-stage model of knowledge management in international joint ventures: Identifying a trigger for knowledge exploration and knowledge harvest. Journal of World Business, 50(1), 180 191.

Pargaonkar, Y. R. (2016). Leveraging patent landscape analysis and ip competitive intelligence for competitive advantage. World Patent Information, 45, 10-20.

Petrisor, I., \& Strain, N. A. (2013). Approaches on the competitive intelligence. USV Annals of Economics \& Public Administration, 13(1), 100-109.

Plessis, M. du. (2007). The role of knowledge management in innovation. Journal of Knowledge Management, 11(4), 20-29.

Purcarea, I., del Mar Benavides Espinosa, M., \& Apetrei, A. (2013). Innovation and knowledge creation: Perspectives on the smes sector. Management Decision, 51 (5), 1096-1107.

Rahimli, A. (2012). Knowledge management and competitive advantage. Information and Knowledge Management, 2(7), 37-43.

Reich, B. H., Gemino, A., \& Sauer, C. (2014). How knowledge management impacts performance in projects: An empirical study. International Journal of Project Management, 32(4), 590-602.

Revilla, E., Prieto, I. M., \& Prado, B. R. (2010). Knowledge strategy: Its relationship to environmental dynamism and complexity in product development. Knowledge and Process Management, 17(1), 36-47.

Rouach, D., \& Santi, P. (2001). Competitive intelligence adds value: Five intelligence attitudes. European Management Journal, 19(5), 552559. 
Roxas, B., Battisti, M., \& Deakins, D. (2013). Learning, innovation and firm performance: Knowledge management in small firms. Knowledge Management Research and Practice, 12(4), 443-453.

Shujahat, M., Hussain, S., Javed, S., Malik, M. I., Thurasamy, R., \& Ali, J. (2017). Strategic management model with lens of knowledge management and competitive intelligence: A review approach. VINE Journal of Information and Knowledge Management Systems, 47(1), 55-93.

Snyman, R., \& Kruger, C. J. (2004). The interdependency between strategic management and strategic knowledge management. Journal of Knowledge Management, 8(1), 5-19.

Sook-Ling, L., Ismail, M. A., \& Yee-Yen, Y. (2015). Information infrastructure capability and organisational competitive advantage. International Journal of Operations \& Production Management, 35 (7), 1032-1055.

Spithoven, A., Vanhaverbeke, W., \& Roijakkers, N. (2013). Open innovation practices in smes and large enterprises. Small Business Economics, 41(3), 537-562.

Street, C. T., \& Meister, D. B. (2004). Small business growth and internal transparency: The role of information systems. MIS Quarterly, 28(3), 473-506.

Sundiman, D. (2017). Human resource management in the enhancement processes of knowledge management. Binus Business Review, 8(3), 167 173.

Sundiman, D., \& Idrus, M. S. (2015). Confucianism ethic, guanxi, and acculturation role on the knowledge transfer process of Chinese descendant in Indonesia. International Journal of Knowledge Management Studies, 6(3), 261.

Sundiman, D., Mursidi, A., \& Putra, S. S. (2016). Knowledge management role on creating service excellence. In Proceedings of the the $11^{\text {th }}$ international knowledge management in organizations conference on the changing face of knowledge management impacting society - kmo '16.

Tambunan, T. (2008). Sme development, economic growth, and government intervention in a developing country: The Indonesian story. Journal of International Entrepreneurship, 6(4), 147-167.

Teece, D. J., Pisano, G., \& Shuen, A. (1997). Dynamic capabilities and strategic management. Strategic Management Journal, 18(7), 509-533.

Teima, G., Berthaud, A., Bruhn, M., DeCastro, O., Joshi, M., Mirmulstein, M., \& Onate, A. (2010). Scaling-up sme access to financial services in the developing world. International Finance Corporation, (October), 1-144.

Tidd, J. (2003). From knowledge management to strategic competence measuring technological, market and organisational innovation, series on technology management. Research Policy, 20, 251-259.

Trim, P. R. J., \&Lee, Y. I. (2008). A strategic marketing intelligence and multi-organizational resilience framework. European Journal of Marketing, 42(7/8), 731-745.

Vajjhala, N. R. (2013). Cultural factors and knowledge sharing in medium-sized enterprises in Albania: A qualitative, multisite case study. University of Phoenix, United States -- Arizona.

Verreynne, M.-L., \& Meyer, D. (2010). Small business strategy and the industry life cycle. Small Business Economics, 35(4), 399-416.

Villa, A., \& Taurino, T. (2017). From industrial districts to sme collaboration frames. International Journal of Production Research, 56(1-2), 1-9.

Vriens, D. J. (2004). The role of information and communication technology in competitive intelligence. In D. J. Vriens (Ed.), Information and Communication Technology for Competitive Intelligence (pp. 1-33). Hershey, PA: Idea Group Publishing.

Werner, K., Dickson, G., \& Hyde, K. F. (2015). Learning and knowledge transfer processes in a mega-events context: The case of the 2011 Rugby World Cup. Tourism Management, 48, 174-187.

Whyman, P. B., \& Petrescu, A. I. (2015). Workplace flexibility practices in smes: Relationship with performance via redundancies, absenteeism, and financial turnover. Journal of Small Business Management, 53(4), 1097-1126.

Wipawayangkool, K., \& Teng, J. T. C. (2016a). Assessing tacit knowledge and sharing intention: A knowledge internalization perspective. Knowledge and Process Management, 23(3), 194206.

(2016b). Paths to tacit knowledge sharing: Knowledge internalization and individual-tasktechnology fit. Knowledge Management Research and Practice, 14 (3), 309-318.

Wolf, S., Just, D., \& Zilberman, D. (2001). Between data and decisions: The organization of agricultural economic information systems. Research Policy, 30(1), 121-141.

Wong, K. Y., \& Aspinwall, E. (2004). Characterizing knowledge management in the small business environment. Journal of Knowledge Management, 8(3), 44-61. 
Zack, M., McKeen, J., \& Singh, S. (2009). Knowledge management and organizational performance: An exploratory analysis. Journal of Knowledge Management, 13(6), 392-409.

Zaim, H., Tatoglu, E., \& Zaim, S. (2007). Performance of knowledge management practices:
A causal analysis. Journal of Knowledge Management, 11(6), 54-67.

Zammuto, R. F., Griffith, T. L., Majchrzak, A., Dougherty, D. J., \& Faraj, S. (2007). Information technology and the changing fabric of organization. Organization Science, 18(5), 749-762. 